\title{
Azospirillum sp. Inoculation in Wheat, Barley and Oats Seeds Greenhouse Experiments
}

\author{
Osmar R. Dalla Santa, Ramona Fernández Hernández, Gergina L. Michelena Alvarez, \\ Pedro Ronzelli Junior and Carlos Ricardo Soccol* \\ Laboratório de Processos Biotecnológicos; Universidade Federal do Paraná; C. P. 19031; 81531-970; \\ soccol@ufpr.br; Universidade Federal do Paraná; Curitiba - PR - Brazil
}

\begin{abstract}
The aim of the present work was to evaluate the inoculation effects of Azospirillum sp. RAM-7 strain, in seeds of wheat, barley and oats cultures on yield and total nitrogen content of the grains in greenhouse experiments. Seeds inoculation with Azospirillum sp. RAM-7 strain enhanced grain yields, even so, the responses vary among the evaluated cultures. For wheat, significant increases were obtained when the inoculation was associated to $100 \%$ of the recommended nitrogen, although the treatment that received only inoculation produced 7.4\% above the control, however this difference wasn't significant. For barley, the presence of the inoculant substituted $20 \%$ the recommended nitrogen fertilization. For oats the inoculation with Azospirillum sp. RAM-7 didn't provide a significant increase in grain yields. In relation to the total nitrogen content of the grains, for all studied cultures, significant differences were not observed among the evaluated treatments $(p<0.05)$.
\end{abstract}

Key words: Azospirillum; Wheat; Barley; Oats; Nitrogen fixation; Plant growth promotion

\section{INTRODUCTION}

In the current agriculture, nitrogen is a limitant nutrient for growth and consequently to the yield of cultures. This element $\left(\mathrm{N}_{2}\right)$ is found in the gaseous form, constituting approximately $78 \%$ of the gases that form the atmospheric air, even so, plants and animals don't get to use it in this form for their metabolism (Döbereiner, 1997; Gyurján et al., 1995).

The plants obtain the nitrogen, mainly by the application of nitrogen fertilizers, industrially synthesized from the atmospheric dinitrogen $\left(\mathrm{N}_{2}\right)$. This element, becomes also available for the plants by the biological fixation of nitrogen (BFN), realized by some bacteria denominated diazotrophic, which possesses an enzymatic apparatus capable to break the triple bound between two nitrogen atoms from the atmospheric nitrogen, forming ammonia that is similar to the industrial process, but without the expense of nonrenewable energetic sources (Döbereiner and Baldani, 1998; Okon and Vanderleyden, 1998; Victoria et al., 1992).

The nitrogen, which is one of the essential elements, is absorbed in great quantities by the plants, needing to be available at high concentration in the soil (Pöttker, 2000). The nitrogen rate utilized for cultures vary according to the organic matter content of the soil, the previous culture and the utilized cultivar. Among the agricultural systems that contribute to the recycle of lost nitrogen to the atmosphere, the most important are the symbioses of bacterias with

*Author for correspondence 
leguminous plants, although, other less specific associations with cereals and various Graminae are standing out (Döbereiner, 1992).

The knowledge of nitrogen biological fixation in non-leguminous plants, mainly in Graminae, among them several cereals, became one of the largest challenges, since these represent the more important alimentary base of the population, mainly in developing countries (Boddey and Döbereiner, 1994; Döbereiner, 1992).

The individual nitrogen need of the six billion inhabitants on earth is the average of 11 g.day $^{-1}$, which is equivalent to $70 \mathrm{~g}$ of protein, or approximately 24 million tons of nitrogen a year. Nowadays, the biological fixation of nitrogen contributes with approximately $35 \%$ of the human diet of the necessary protein for everyone (Vance, 1999). The great importance of the nitrogen resides in the fact that it is an essential constituent of the proteins, nucleic acids and other compounds of nitrogen bases, essential to the vital processes of all live beings (Payne et al., 1981).

Microorganisms capable of fixing nitrogen in free life, in spite of important in number, in general contribute a little with fixed nitrogen. The effects of those bacterias are mainly in the promotion of plants root growth, as they produce growthpromoting substances. The great interest in the biological fixation of nitrogen in Graminea is related to the better utilization of water by these cultures, in relation to the leguminous plants and also by showing better photosynthetic effectiveness by its great majority. Being the Graminea broadly used as food by the man, even if, a part of the nitrogen was just supplied by the association with bacterias, the utilization of nitrogen fertilizers would save the same amount or it would be superior as the verified for leguminous plants, which can be self-sufficient in nitrogen (Döbereiner, 1992).

The genera Azospirillum, Herbaspirillum, Azobacter and Acetobacter show generalized occurrence in economically important cultures such as corn, wheat, rice, sorghum and sugar cane, like this being with frequency, in experiments seeking the agronomic utilization as biofertilizers (Döbereiner, 1997; Reinhold and Hurek, 1988; Sundaram et al., 1988). The bacterias of the Azospirillum genera presents application potential in agricultural systems, around $70 \%$ of the experiments up to $30 \%$ in productivity (Bashan and Holguin, 1997; Dalla Santa et al., 2004;
Fani et al., 1995; Katupitiya et al., 1995; Machado et al., 1998; Sumner, 1990).

Azospirillum bacterias form different types of association in diverse vegetables species. Initially it was believed that they were found only at the rhizosphere, but later on they were isolated from the soil and also certain endophytic strains, which are capable to colonize internally the plant, supplying the nitrogen with more efficiency (Assmus, et al., 1995; Bashan and Levanony, 1990; Döbereiner et al., 1995; Fischer, et al., 2003; Hauwaerts, et al., 2002; Hecht-Buchholz, 1998; James, 2000; Kirchhof et al. 1997; Ramos, et al., 2002).

The promotion of plants growth inoculated with Azospirillum has been obtained in field conditions and greenhouse experiments, resulting in significant changes in several characteristics of the plants. The inoculation can cause increase in the dry weight and in the accumulation of total nitrogen of the plant, in the grain yields and in the weight of the grains, in the germination rate of the seeds and in changes in the duration of the plants growth stages (Boddey and Döbereiner, 1988; Fages, 1994; Fallik and Okon, 1996; Nur et al., 1980; Pandey et al 1998; Sumner, 1990).

The beneficial effects caused by the inoculation with Azospirillum are not only due to FBN in the rhizosphere, but mainly, for the best efficiency in the absorption of water and nutrients, which happens due to a more developed root system, increasing the soil area explored by the roots. This better development of the plants root system, inoculated with Azospirillum, is caused by the capacity that a lot of strains present in producing growth promoters substances of plants (Bashan and Holguin, 1997; Boddey et al., 1986; Döbereiner, 1992; Fallik and Okon, 1996; Kucey, 1988; Reis et al., 2000)

The Azospirillum inoculation responses in nonleguminous plants are still difficult to estimate. The results inconsistency in inoculation experiments is related with the inoculation techniques, inoculation rate, low survival of inoculated strains, physical and chemical characterization of the soil, physiological state of the bacteria, improper strain, plant genotype, presence of high number of native microorganisms and pesticides influence. (Bashan et al., 1995; Fages,1994; Itzigsohn et al. 1995).

The present work had as objective to verify the Azospirillum sp. RAM-7 inoculation effect in seeds of wheat, barley and oats on grain yield and nitrogen content of the grains by the representative 
importance of cost reduction with nitrogen fertilization in food production.

\section{MATERIAL AND METHODS}

\section{Inoculant production}

The strain of Azospirillum sp. RAM-7 was obtained from Instituto Cubano de Investigaciones de los Derivados de la Caña de Azúcar (ICIDCA). This strain present good biomass production, and in preliminary tests with other cultures increased de yield. The biomass of Azospirillum utilized as inoculant was produced in a MDL Marubishi fermenter, at Biotechnological Processes Laboratory of Federal University of Paraná. The fermentation conditions and the utilized composition of the culture media were the same as described by Fernández et al. (1999). The final concentration of Azospirillum sp. RAM-7 strain in the fermentation broth was of $10^{10} \mathrm{CFU} \cdot \mathrm{mL}^{-1}$, this broth was maintained at $4^{\circ} \mathrm{C}$ until utilization as inoculant.

\section{Greenhouse experiment}

The experiments with wheat cultivars OR-1, barley BR-2 utilized for beer production and oats FAPA-1, were implemented in greenhouse at the Agronomic Sector of Federal University of Paraná. Different nitrogen fertilization levels associated or not with the inoculation of Azospirillum sp. RAM7 strain were evaluated. The assay was composed of the following treatments: control (without nitrogen and uninoculated); inoculated (IN); IN associated to $20,40,60,80$ e $100 \%$ of nitrogen $(\mathrm{N})$ recommended for each culture and the treatment with $100 \%$ nitrogen and uninoculated.

For wheat, the recommended ideal fertilization with nitrogen was $84 \mathrm{mg} / \mathrm{dm}^{3}$ of soil, for barley and oats $56 \mathrm{mg} / \mathrm{dm}^{3}$ of soil. The nitrogen fertilization with urea as $\mathrm{N}$ source was applied in portions during inoculation, and at the seed coating at the beginning of the sowing. The fertilization with phosphorus $\left(\mathrm{P}_{2} \mathrm{O}_{5}\right)$ and potassium $\left(\mathrm{K}_{2} \mathrm{O}\right)$ were the same for all the treatments of the three cultures, being 350 and $80 \mathrm{mg} / \mathrm{dm}^{3}$ of soil, respectively at planting.

The inoculation with Azospirillum sp. RAM-7 was done immediately before planting by the method of seeds coating contamination by utilizing the fermentation broth with concentration of $10^{9}$ CFU.mL ${ }^{-1}$. For the three cultures, the inoculation potential with Azospirillum sp. RAM-7 was $10^{6}$ CFU.g ${ }^{-1}$ of seed.

The experimental unities were composed by pots containing $5 \mathrm{~kg}$ of previously sieved soil, disposed in complete randomized blocks with four repetitions for each treatment. In each experimental unit 10 seeds were planted, after germination three plants for experimental unity were aleatory selected. All the necessary treatments for adequate development of the cultures were realized, such as control of weeds, fungicide application and irrigation.

\section{Analysis}

The treatments effects on the assays with wheat, barley and oats were evaluated in relation to grain yield (grams per pot), and total nitrogen content of the grains was estimated by the Kjeldahl method (AOAC, 1996). The averages were statistically compared using Tukey multiple test at significance $\mathrm{P}=0.05$.

\section{RESULTS AND DISCUSSION}

\section{Azospirillum sp. RAM-7 strain inoculation in wheat seeds, cultivar OR-1}

The averages of grain yield and total nitrogen content of the experiment with wheat cultivar OR1 , are demonstrated in Table 1. The obtained data permitted to verify that the wheat seeds inoculated with Azospirillum sp. RAM-7 strain enhanced grain yield.

The treatment that received only inoculation produced $7.4 \%$ above the control, although this difference wasn't significant $(\mathrm{p}<0.05)$. When the inoculation was associated to $100 \%$ of the $\mathrm{N}$ recommended for the experiment, it was verified a significant augmentation in grains production, being $9.0 \%$ superior in relation to the treatment with $100 \%$ of $\mathrm{N}$ and uninoculated $(\mathrm{p}<0.05)$. Significant enhances in wheat grains yields, in treatments associating Azospirillum with mineral nitrogen fertilization are described in literature. Although, normally the greatest enhances on grain yield caused by Azospirillum sp. inoculation are obtained in association to doses of nitrogen inferior to greatest dose (Didonet et al., 1996; Millet et al., 1984; Raí and Guar, 1988; Sumner, 1990). 
Table 1 - Grain yield and total nitrogen content of wheat grains, cultivar OR-1, inoculated with Azospirillum sp. RAM-7 strain.

\begin{tabular}{lcc}
\hline \multicolumn{1}{c}{ Treatments } & Grain yield (grams/pot) & Grain total nitrogen (\%) \\
\hline Control (C) & $3.24 \mathrm{~g}^{1}$ & $1.75 \mathrm{a}$ \\
Inoculated (IN) & $3.48 \mathrm{~g}$ & $1.73 \mathrm{a}$ \\
IN $+20 \%$ of N & $5.21 \mathrm{f}$ & nd \\
IN $+40 \%$ of N & $7.81 \mathrm{e}$ & nd \\
IN $+60 \%$ of N & $9.36 \mathrm{~d}$ & $\mathrm{nd}$ \\
IN $+80 \%$ of N & $11.66 \mathrm{c}$ & $1.72 \mathrm{a}$ \\
IN $+100 \%$ of N & $15.28 \mathrm{~b}$ & $1.70 \mathrm{a}$ \\
$100 \%$ of N & $14.02 \mathrm{a}$ & \\
Means followed by the different letters in the same column are statistically different according to Tukey's multiple range tests \\
(P<0.05).
\end{tabular}

These grain yield increases, caused by the inoculation with Azospirillum are not just related with the capacity that these bacterias present in fix the atmospheric nitrogen but also, due to the production of plant growth promoting substances. These phytohormones promote the root growth of the plants, consequently increasing nutrients and water absorption areas (Barbieri et al., 1986; Creus et al., 1996; Kucey, 1988; Reis et al., 2000; Steenhoudt and Vanderleyden, 2000).

In relation to the accumulation of total nitrogen in the wheat grains, significant differences were not observed by the inoculation of Azospirillum sp. RAM-7 strain between the evaluated treatments $(\mathrm{p}<0.05)$.

\section{Azospirillum sp. RAM-7 inoculation in barley seeds, cultivar BR-2 utilized for beer production}

For barley, Azospirillum sp. RAM-7 strain provided an increase on grain yield. The averages of yield and total nitrogen content of the grains are demonstrated in Table 2. In spite of being statistically similar, the treatment that received only the inoculum (IN) had a superior productivity in relation to the control $(\mathrm{C})$.

The positive effect caused by the bacteria inoculation on grain yield was also observed by comparing the treatments that received the ideal quantity of the recommended nitrogen fertilization for the experiment. The grain yield of the treatment in which the inoculation is associated to $100 \%$ of the $\mathrm{N}$ fertilization, was $6 \%$ superior, in relation to the treatment that received the same $\mathrm{N}$ fertilization content without inoculation $(\mathrm{p}<0.05)$. The production of the treatments inoculated and associated to $80 \%$ of $\mathrm{N}$ and with $100 \%$ of $\mathrm{N}$ without inoculation were statistically similar being, demonstrated in this case that the presence of the inoculant substituted $20 \%$ of the recommended $\mathrm{N}$ fertilization for this experiment. In relation to total nitrogen content of the grains, it was observed that the nitrogen chemical supply was essential for a larger accumulation in the evaluated tissues. However, the inoculation with Azospirillum sp. RAM-7 didn't provide larger accumulation of nitrogen in the grains (Table 2). The greater accumulation of nitrogen in the grains, caused by the inoculation of bacterias of the genera Azospirillum, is due to a larger nitrogen offer for the plant. This larger offer can be consequence of nitrogen biological fixation process accomplished by the bacterias, or the capacity of certain strains in reducing the nitrate, or that the inoculated plants present a more developed root system, allowing the exploration of a larger soil area (Baldani et al., 1983; Boddey and Döbereiner, 1988; Boddey et al., 1986; Christiansen-Weniger and Van Veen, 1991; Didonet et al., 1996; Döbereiner, 1992; Fages, 1994; Ferreira et al., 1987; Kapulnik et al., 1981; Raí and Guar, 1988).

Few data of inoculant application with Azospirillum in barley is found. The inoculation of barley seeds with Azospirillum brasilense increased dry matter and barley grains yield, even so, this increase was not significant. Significant increases happened when the inoculation of the bacteria was associated to different endophytic fungi (Rao, 1981). 
Table 2 - Yield and total nitrogen content of barley grains, cultivar BR-2, inoculated with Azospirillum sp. RAM-7 strain.

\begin{tabular}{|c|c|c|}
\hline Treatments & Grain yield (grams/pot) & Grain total nitrogen $(\%)$ \\
\hline Control $(\mathrm{C})$ & $4.16 \mathrm{f}^{1}$ & $1.30 \mathrm{~b}$ \\
\hline Inoculated (IN) & $5.01 \mathrm{f}$ & $1.32 \mathrm{~b}$ \\
\hline $\mathrm{IN}+20 \%$ of $\mathrm{N}$ & $6.32 \mathrm{e}$ & nd \\
\hline $\mathrm{IN}+40 \%$ of $\mathrm{N}$ & $8.61 \mathrm{~d}$ & nd \\
\hline $\mathrm{IN}+60 \%$ of $\mathrm{N}$ & $11.00 \mathrm{c}$ & nd \\
\hline $\mathrm{IN}+80 \%$ of $\mathrm{N}$ & $13.12 \mathrm{~b}$ & nd \\
\hline $\mathrm{IN}+100 \%$ of $\mathrm{N}$ & $15.52 \mathrm{a}$ & $1.39 \mathrm{a}$ \\
\hline $100 \%$ of $\mathrm{N}$ & $14.64 \mathrm{~b}$ & $1.36 \mathrm{ab}$ \\
\hline
\end{tabular}

Azospirillum sp. RAM-7 strain inoculation in oats seeds, cultivar FAPA-1

For the oats, growing increases in yield were observed by the elevation of applied nitrogen doses, even so, the inoculation with Azospirillum sp. RAM-7, didn't provide a significant increase in yield and total nitrogen content of the grains (Table 3). These results were obtained even for the treatment that received only the inoculation as for the treatment associated to $100 \%$ of mineral nitrogen fertilization, recommended for this assay.

Table 3 - Yield and total nitrogen content of oats grains, cultivar FAPA-1, inoculated with Azospirillum sp. RAM-7 strain.

\begin{tabular}{lcc}
\hline \multicolumn{1}{c}{ Treatments } & Grain yield (grams/pot) & Grain total nitrogen $(\%)$ \\
\hline Control (C) & $3.94 \mathrm{e}^{\mathrm{l}}$ & $1.30 \mathrm{~b}$ \\
Inoculated (IN) & $3.95 \mathrm{e}$ & $1.32 \mathrm{~b}$ \\
IN $+20 \%$ of N & $5.59 \mathrm{de}$ & $\mathrm{nd}$ \\
IN $+40 \%$ of N & $7.04 \mathrm{~d}$ & $\mathrm{nd}$ \\
IN $+60 \%$ of N & $9.37 \mathrm{c}$ & $\mathrm{nd}$ \\
IN $+80 \%$ of N & $11.38 \mathrm{~b}$ & $1.39 \mathrm{a}$ \\
IN $+100 \%$ of N & $14.64 \mathrm{a}$ & $1.36 \mathrm{ab}$ \\
$100 \%$ of N & $14.17 \mathrm{a}$ & \\
\hline
\end{tabular}

${ }^{1}$ Means followed by the different letters in the same column are statistically different according to Tukey's multiple range tests $(\mathrm{P}<0.05)$.

nd - not determined

The effects of Azospirillum sp. RAM-7 inoculation were different in the three evaluated cultures. The specificity in the association of the plant and bacteria strain was observed in several experiments accomplished with different cultivars, as well as, among the different cultures (Millet et al., 1984). In this way, for the intensive use of inoculants with associative bacterias, it is needed a wide isolation, to select inside of the great existent diversity, the best combination between genotype of the plant and bacteria strain, as well as, the selection of efficient bacterias in the colonization of the roots, nitrate reducer, producer of phytohormones and capable to fix significant amounts of nitrogen (Baldani et al., 2002).
The agronomic use of Azospirillum is being extensively tested, and the results about the cultures yield are inconsistent. This inconsistency can be related with the not controlled field conditions, technique and inoculation rate, low survival of the inoculated strains, physical and chemical characteristics of the soil, physiologic state of the bacteria, inappropriate strain, plant genotype, presence of high number of native microorganisms and pesticides influence (Bashan et al., 1995; Chotte et al., 2002; Itzigsohn et al., 1995; Ramos et al., 2002). More consistent results are necessary, for the commercial development of inoculants with Azospirillum (Fages, 1994). Constant responses, caused by the inoculation of 
Azospirillum resulting in yield increases above $20 \%$ are considered commercially viable, for the current agriculture (Bashan and Levanony, 1990).

\section{RESUMO}

O presente trabalho teve por objetivo avaliar os efeitos da inoculação de Azospirillum sp. RAM-7, em sementes das culturas de trigo, cevada e aveia sobre a produtividade e teor de nitrogênio total dos grãos, em experimentos implantados em de casade-vegetação. A inoculação das sementes com Azospirillum sp. RAM-7 aumentou a produtividade, porém, estas respostas variam entre as culturas avaliadas. Para o trigo, aumentos significativos foram obtidos quando a inoculação foi associada a $100 \%$ do nitrogênio recomendado, já o tratamento que recebeu somente inoculação produziu $7,4 \%$ acima do controle, porém, esta diferença não foi significativa. Para a cevada, a presença do inoculante substituiu $20 \%$ da adubação recomendada de nitrogênio. Para a aveia, a inoculação com Azospirillum sp. RAM-7 não proporcionou aumento significativo na produtividade. Em relação ao teor de nitrogênio total dos grãos, para as três culturas, não foram observadas diferenças significativas entre os tratamentos avaliados $(\mathrm{p}<0,05)$.

\section{REFERENCES}

AOAC (1996), Official Methods of Analysis. $17^{\text {th }}$ ed. Arlington, Virginia, USA: Association of Official Analytical Chemists.

Assmus, B.; Hutzler, P.; Kirchhof, G.; Amann, R.; Lawrence, J. R. and Hartmann, A. (1995), In situ localization of Azospirillum brasilense in the rhizosphere of wheat with fluorescently labeled, rRNA-targeted oligonucleotide probes and scanning confocal laser microscopy. Appl. Environ Microb., 61, 1013-1019.

Baldani, J. I.; Reis, V. M.; Teixeira, K. R. S. and Baldani, V. L. D. (2002), Potencial biotecnológico de bactérias diazotróficas associativas e endofíticas. In: Serafini, L. A.; Barros, N. M. and Azevedo, J. L. (Eds.). Biotecnologia: avanços na agricultura e na agroindústria. Caxias do Sul : EDUCS. pp. 195-232.

Baldani, V. L. D.; Baldani, J. I. and Döbereiner, J. (1983), Effects of Azospirillum inoculation on root infection and nitrogen incorporation in wheat. Can. J. Microbiol., 29, 924-929.
Barbieri, P.; Zanelli, T.; Galli, E. and Zanetti, G. (1986), Wheat inoculation with Azospirillum brasilense Sp6 and some mutans altered in nitrogen fixation and indole-3-aceticacid prodution. Microbiol. Lett., 36, 87-90.

Bashan, Y. and Levanony, H. (1990), Current status of Azospirillum inoculation technology: Azospirillum as a challenge for agriculture. Can. J. Microbiol., 36, 591-603.

Bashan, Y.; Puente, E.; Rodríguez-Mendonza, N. N.; Holguin, G.; Toledo, G.; Ferrera-Cerrato, R. and Pedrin, S. (1995), Soil parameters which affect the survival of Azospirillum brasilense. In: Fendrik, I.; Del Gallo, M.; Vanderleyden, J. and Zamaroczy, M. (Eds.). Azospirillum and related microorganisms. Germany : Springer Verlag. pp. 441-450.

Bashan, Y. and Holguin, G. (1997), Azospirillum-plant relationships: environmental and physiological advances (1990-1996). Can. J. Microbiol., 43, 103-121.

Boddey, R. M.; Baldani, V. L. D.; Baldani, J. I. and Döbereiner, J. (1986). Effect of inoculation of Azospirillum spp. on nitrogen accumulation by fieldgrown wheat. Plant Soil, 95, 109-121.

Boddey, R. M. and Döbereiner, J. (1988), Nitrogen fixation associated with grasses and cereals: Recent results and perspectives for future research. Plant Soil, 108, 53-65.

Boddey, R. M. and Döbereiner, J. (1994), Biological nitrogen fixation associated with graminaceous plants. In: Okon, Y. (Ed.). Azospirillum Plant Associations. USA : CRC-Press. pp. 119-130.

Chote, J.; Schwatzamann, A.; Bally, R. and Monrozier, L. J. (2002), Changes in bacterial communities and Azospirillum diversity in soil fractions of a tropical soil under 3 or 19 years of natural fallow. Soil Biol. Biochem., 34, 1083-1092.

Christiansen-Weniger, C. and Van Veen, J. A. (1991), $\mathrm{NH}_{4}{ }^{+}$- Excreting Azospirillum brasilense mutants enhance the nitrogen supply of a wheat host. Appl. Environ. Microb., 57, 3006-3012.

Creus, C. M.; Sueldo, R. J. and Barassi, C. A. (1996). Azospirillum inoculation in pregerminating wheat seeds. Can. J. Microbiol., 42, 83-86.

Dalla Santa, O. R.; Soccol, C. R.; Ronzelli, P.; Hernández, R. F.; Alvarez, G. L. M.; Dalla Santa, H. S. and Pandey, A. (2004), Effects of inoculation of Azospirillum sp. in maize seeds under field conditions. Food, Agriculture and Environment (JFAE), 2, 238-242.

Didonet, A. D.; Rodrigues, O. and Kenner, M. H. (1996), Acúmulo de nitrogênio e de massa seca em plantas de trigo inoculadas com Azospirillum brasilense. Pesqui. Agropecu. Bras., 31, 645-651.

Döbereiner, J. (1997), A importância da fixação biológica de nitrogênio para a agricultura sustentável. Biotecnologia Ciência and Desenvolvimento Encarte especial, 1, 2-3. 
Döbereiner, J. (1992), Fixação de nitrogênio em associação com gramíneas. In: Cardoso, E. J. B. N. (Ed.). Microbiologia do solo. Campinas : Sociedade Brasileira de Ciências do Solo. pp. 173-180.

Döbereiner, J. and Baldani, V. L. D. (1998), Novas tecnologias biocombustíveis. Biotecnologia Ciência and Desenvolvimento, 4, 16-17.

Döbereiner, J.; Baldani, V. L. D. and Baldani, J. I. (1995), Como isolar e identificar bactérias diazotróficas de plantas não-leguminosas. Brasilia: EMBRAPA - SPI: Itaguí : EMBRAPA-CNPAB. pp. 19-25.

Fages J. (1994), Azospirillum inoculants and field experiments, In: Okon, Y. (Ed.). Azospirillum Plant Associations. USA : CRC Press. pp. 88-105.

Fallik, E. and Okon, Y. (1996), The response of maize (Zea mays) to Azospirillum inoculation in various types of soils in the field. World J. Microb. Biot., 12, 511-515.

Fani, R.; Bandi, C.; Bazzicalupo, M.; Damiani, G.; Di Cello, F.; Fancelli, S.; Gallori, E.; Gerace, L.; Grifoni, A.; Liò, P. and Mori, E. (1995), Phylogenetic studies of the genus Azospirillum. In: Fendrik, I.; Del Gallo, M.; Vanderleyden, J. and Zamaroczy, M. (Eds.). Azospirillum and related microorganisms. Germany : Springer Verlag. pp. 59-75.

Fernández, R.; Dalla Santa, O. R.; Soccol, C. R. and Michelena, G. (1999), Obtención de un inoculante comercial a partir de Azospirillum sp. en condiciones brasileñas. Revista sobre los Derivados de la Caña de Azucar - ICIDCA, 23.

Ferreira, M. C. B.; Fernandes, M. S. and Dóbereiner, J. (1987), Role of Azospirillum brasilense nitrate reductase in nitrate assimilation by wheat plants. Biol. Fert. Soils, 4, 1-7.

Fischer, S. E.; Miguel, M. J. and Mori, G. B. (2003), Effect of root exudates on the exopolysaccharide composition and the lipopolysaccharide profile of Azospirillum brasilense $\mathrm{Cd}$ under saline stress. FEMS Microbiol. Lett., 219, 53-62.

Gyurján, I.; Korányi, P.; Preininger, E.; Varga, S. S. and Paless, G. (1995), Artificial Plant-Azobacter symbiosis for atmospheric nitrogen fixation. In: Fendrik, I.; Del Gallo, M.; Vanderleyden, J. and Zamaroczy, M. (Eds.). Azospirillum and related microorganisms. Germany : Spring Verlag. pp. 401-413.

Hauwaerts, D.; Alexandre, G.; Das, S. K.; Vanderleyden, J. and Zhulin, I. B. (2002), A major chemotaxis gene cluster in Azospirillum brasilense and relationships between chemotaxis operons in alfa-proteobacteria. FEMS Microbiol. Lett., 208, 61-67.

Hecht-Buchholz, C. (1998), The apoplast-habitat of endophytic dinitrogen-fixation bacteria and their significance for the nitrogen nutrition of nonleguminous plants. Z. Pflanzenernähr. Bodenk., 161, 509-520.
Itzigsohn, R.; Abbass, Z.; Sarig, S. and Okon, Y. (1995), Inoculation effects of Azospirillum on sunflowers (Helianthus annus) under different fertilization and irrigation regimes. In: Fendrik, I.; Del Gallo, M.; Vanderleyden, J. and Zamaroczy, M. (Eds.). Azospirillum and related microorganisms. Germany : Springer Verlag. pp. 503-513.

James, E. K. (2000), Nitrogen fixation in endophytic and associative symbiosis. Field Crop Res., 65, 197-209.

Kapulnik, J.; Kigel, J., Okon, Y.; Nur, I. and Henis, Y. (1981), Effect of Azospirillum inoculation on some growth parameters and N-content of wheat, sorghum and panicum. Plant Soil., 61, 65-70.

Katupitiya, S.; Millet, J.; Vesk, M.; Viccars, L.; Zeman, A.; Lidong, Z.; Elmerich, C. and Kennedy, I. (1995), A mutant of Azospirillum brasilense $\mathrm{Sp} 7$ impaired in flocculation with a modified colonization pattern and superior nitrogen fixation in association with wheat. Appl. Environ. Microb., 61, 1987-1995.

Kirchhof, G.; Reis, V. M.; Baldani, J. I.; Eckert, B.; Döbereiner, J. and Hartmann, A. (1997), Occurrence, physiological and molecular analysis of endophytic diazotrophic bacteria in gramineous energy plants. Plant Soil, 194, 45-55.

Kucey, R. M. N. (1988), Alteration of size of wheat root systems and nitrogen fixation by associative nitrogen-fixing bacteria measured under field conditions. Can. J. Microbiol., 34, 735-739.

Machado, H. B.; Souza, E. M.; Picheth, C. F.; Ishida, M. L.; Steffens, M. B. R.; Rigo, L. U.; Chubatsu, L. S.; Vitorino, J. C.; Legg, L. A.; Delboni, L. F.; Yates, M. G. and Pedrosa, F. O. (1998), Promoção do crescimento vegetal por Azospirillum: fato ou ficção? In: Encontro Paranaense de Biotecnologia Aplicada a Agropecuária, Londrina. Anais... Londrina. pp. 12-17.

Millet, E.; Avivi, Y. and Feldman, M. (1984), Yield response of various wheat genotypes to inoculation with Azospirillum brasilense. Plant Soil., 80, 261-266.

Nur, I.; Okon, Y. and Henis, Y. (1980): An increase in nitrogen content of Setaria italica and Zea mays inoculaited with Azospirillum. Can. J. Microbiol., 26, 482-485.

Okon, Y. and Vanderleyden, J. (1998), Root-associated Azospirillum species can stimulate plants. Features, 63, 366-370.

Pandey, A.; Sharma, E. and Palni, L. M. S. (1998), Influence of bacterial inoculation on maize in upland farming systems of the Sikkim himalaya. Soil Biol. Biochem., 30, 379-384.

Payne, W. J.; Sherr, B. F. and Chalmers, A. (1981), Nitrification-denitrification associated with plant roots. In: Vose, P. B. and Ruschel, A. P. (Eds.). Associative $\mathrm{N}_{2}$-Fixation. Florida : CRC Press. pp. 37-48.

Pöttker, D. (2000), Recentes avanços no manejo químico do solo para a cultura do milho. In: Sandini, I. E. and Fancelli, A. L. (Eds.). Milho: Estratégias de manejo para a região sul. Guarapuava : Fundação Agrária de Pesquisa Agropecuária. pp. 63-87. 
Rai, S. N. and Guar, A. C. (1988), Characterization of Azobacter spp. and effect of Azobacter and Azospirillum as inoculant on the yield and N-uptake of wheat crop. Plant Soil., 109, 131-134.

Ramos, H. J. O.; Roncato-Maccari, L. D. B.; Souza, E. M.; Soares-Ramos, J. R. L.; Hungria, M. and Pedrosa, F. O. (2002), Monitoring Azospirillum-wheat interactions using the gfp and gusA genes constitutively expressed from a new broad-host range vector. J. Biotechnol., 97, 243-252.

Rao, N. S. S. (1981), Response of crops to Azospirillum inoculation in Índia. In: Vose, P. B. and Ruschel, A. (Eds.). P. Associative $\mathrm{N}_{2}$-Fixation. Florida : CRC Press. pp. 137-144.

Reinhold, B. and Hurek, T. (1988), Location of diazotrophs in the root interior with special attention to the kallar grass association. Plant Soil, 110, 259-268.

Reis, V. M.; Baldani, J. I.; Baldani, V. L. D. and Döbereiner, J. (2000), Biological dinitrogen fixation in gramineae and palm trees. Plant Science, 19, 227-274.

Steenhoudt, O. and Vanderleyden, J. (2000), Azospirillum, a free living nitrogen-fixing bacterium closely associated with grasses: genetic, biochemical and ecological aspects. Fems Microbiol. Rev., 24, 487-506.

Sumner, M. E. (1990), Crop responses to Azospirillum inoculation. In: Stewat, B. A. (Ed.). Advances in Soil Science. New York : Springer-Verlag. pp. 52-123.

Sundaram, S.; Arunakumari, A. and Klucas, R. V. (1988), Characterization of Azospirilla isolated from seeds and roots of turf gras. Can. J. Microbiol., 34, 212-217.

Vance, C. P. (1999), Nitrogen fixation in agriculture: Where are the needs? In: Internacional Congress on Nitrogen Fixation, 12 ${ }^{\text {th }}$, Foz do Iguaçú, Paraná. 9 (Abstract).

Victoria, R. L.; Piccolo, M. C. and Vargas, A. A. T. (1992), O Ciclo do nitrogênio. In: Cardoso, E. J. B. N. (Ed.). Microbiologia do Solo. Campinas. pp. 105-117.

Received: July 23, 2003; Revised: October 20, 2003 ; Accepted: June 11, 2004. 